\title{
CDISC SDTM Coronary Vessel Disease Extent Terminology
}

National Cancer Institute

\section{Source}

National Cancer Institute. CDISC SDTM Coronary Vessel Disease Extent Terminology. NCI Thesaurus. Code C101850.

Terminology associated with the coronary vessel disease extent codelist of the Clinical Data Interchange Standards Consortium (CDISC) Study Data Tabulation Model (SDT M). 